\title{
Duel fuel compression ignition engine fuelled with homogeneous mixtures of propane and kerosene-based fuel
}

\begin{abstract}
The paper presents some results of examination of DF CI engine fuelled with kerosene-based fuel (Jet A-1) and propane. The aim was to obtain the maximum engine thermal and overall efficiency and checking the engine emissions for the application of significant share of propane as a main source of energy. The fuel which initiates the ignition was Jet A-1 provided by common rail system during the beginning of compression stroke. Propane was provided to inlet manifold in a gas phase. The method of providing of both fuels to the engine cylinder allowed to create nearly homogeneous mixture and realized HCCI process for dual fueling with Jet A-1 and propane. It was possible to compare two combustion strategies PCCI and HCCI for fuelling of CI engine with single fuel (Jet A-1) and dual fuelling with Jet A-1 and propane. The results of experiment show that the $\mathrm{NO}_{x}$ and soot emissions are much lower than for standard CI or SI engines. The results also show very interesting potential role of propane in control of HCCI dual fuel combustion process which gives the new perspective of dual fuel engine development. The low levels of toxic components in exhaust gases encourage to test and develop this type of fuelling which could radically confine the negative influence on the environment as well as enable to apply an alternative fuels.
\end{abstract}

Key words: dual-fuel engine, kerosene-based fuel, propane, HCCI process, low $\mathrm{NO}_{x}$ emission

\section{Introduction}

Despite of anti-diesel campaign which is undertaken by some authorities especially municipal authorities from large cities to promote electromobility compression ignition engines are still widely used for transportation and power generation and have rather good perspective. There are many reasons for that:

1. High fuel efficiency - about $20 \%$ less fuel consumed than equivalent petrol cars.

2. $15 \%$ less $\mathrm{CO}$ - emissions $/ \mathrm{km}$ than equivalent petrolpowered vehicles. Diesel vehicles contribute to reduce $\mathrm{CO}_{2}$ emissions from road transport and therefore to mitigating climate change.

3. 2021 targets - while petrol and diesel engines will continue to improve efficiency, diesel will continue to be important in meeting EU's $2021 \mathrm{CO}_{2}$ fleet average targets and beyond.

4. Heavy duty - diesel engines are suited for use in heavier commercial or long-haul commercial vehicles, which is why they will remain difficult to replace for trucks and vans.

5. Longer range - diesel's high fuel economy ensures a longer range between refuelling stops [8].

However, diesel engines can cause environmental pollution owing to their high $\mathrm{NO}_{\mathrm{x}}$ and soot emissions. Emission aftertreatment devices have problems in terms of their cost and durability. Since emission aftertreatment systems such as Diesel Particulate Filters (DPF), Lean NOx Trap (LNT) and Selective Catalytic Reduction (SCR) systems also often increase fuel consumption, in-cylinder technologies for emission reduction have therefore been the focus of intense research [10]. Considerable effort has thus been devoted toward reducing these pollutant emissions as these have adverse effects on the environment and human health [5].

The are some areas for research to make CI engine more environmental friendly as well as more efficient. First of all revolutionary in-cylinder combustion strategies, especially low-temperature combustion, could convert the combustion process to more clean and more effective process. It also can be connected with application of alternative fuels, especially more clean gas fuels. When we add new generation exhaust emission aftertreatment systems which will meet stringent emission regulations the future of CI engine looks right.

The paper presents some results of research on combustion of kerosene-based fuel (Jet A-1) and dual fuel combustion of kerosene-based fuel (Jet A-1) together with propane in CI engine for low loads and constant engine speed.

Depending on the way of fueling two combustion strategies were examined during the tests:

- PCCI (premixed charge compression ignition) - fueling with Jet A-1 only and dual fueling with Jet A-1 and propane for standard injection timing of Jet A-1

- HCCI (homogeneous charge compression ignition) fueling with Jet A-1 only as well as dual fueling with Jet A-1 and propane.

\section{Propane - clean fuel for $\mathrm{IC}$ engine}

Propane $\left(\mathrm{C}_{3} \mathrm{H}_{8}\right)$ has been recognized as a clean fuel for last decades. The reason is that compared to the gasoline or diesel oil used as a automotive fuel, propane fuel gives about 25\% fewer greenhouse gases. When the unburned propane is released into the atmosphere it doesn't contribute to the greenhouse effect. However, other clean fuels (such as natural gas) contribute greatly to global warming if released before combustion. For instance unburned methane in natural gas creates 25 times more greenhouse gases than carbon dioxide [11].

Despite declines in oil prices, propane production is expected to continue to grow. This should enable propane to remain competitively priced relative to gasoline and diesel fuel in engine fuel market. It is sold as a clear propane (especially on US market) or as a part of LPG fuel. Although processing has changed in many ways over the years, there are still two main ways that propane is produced today: refining, and natural gas production. Because natural gas production is growing and propane makes up about $5 \%$ of 
unprocessed natural gas the production of propane is also growing. The same is happening for propane production from crude oil refining (propane is also a natural byproduct in the crude oil refining process). The actual percentage of propane extracted from the crude oil depends on the process and the type of refinery [12]. The additional reason for propane sale growth is that propane could be also produced from $100 \%$ renewable raw materials such as waste and residues and sustainably produced vegetable oils. In use, renewable propane is identical to conventional propane and, therefore, can easily be blended with conventional propane and used by all existing appliances suitable for use with propane [13]. As far as transportation infrastructure constraints resulting from the rapid growth in natural gas liquid (LNG) production, propane sales for use in internal combustion engines are projected to grow steadily, as clean propane applications (such as commercial lawn mowers, irrigation pumps, and propane vehicles) become more widespread in the marketplace [14].

In the experiment described in the paper propane was used as a second fuel which modified the combustion process of Jet A-1 fuel in CI AVL experimental engine. So, the engine was dual-fueled with kerosene based fuel Jet A-1 and propane. Chosen physical properties for Jet A-1 vs. propane are described in Table 1.

Table 1. Chosen physical properties for Jet A-1 vs. propane

\begin{tabular}{|c|c|c|}
\hline Parameter & Jet A-1 [10] & Propane \\
\hline Flash point $\left[{ }^{\circ} \mathrm{C}\right]$ & 38 & -104 \\
\hline $\begin{array}{l}\text { Autoignition } \\
\text { temperature }\left[{ }^{\circ} \mathrm{C}\right]\end{array}$ & 210 & 470 \\
\hline $\begin{array}{l}\text { Max adiabatic burn tempera- } \\
\text { ture }\left[{ }^{\circ} \mathrm{C}\right]\end{array}$ & 2230 & $1980[11]$ \\
\hline Density at $\left[15^{\circ} \mathrm{C}\right]$ & $0.804 \mathrm{~kg} / 1$ & $1.882 \mathrm{~kg} / \mathrm{m}^{3}$ \\
\hline Specific energy $[\mathrm{MJ} / \mathrm{kg}]$ & 42.8 & 50.34 \\
\hline Distillation & $\begin{array}{c}\text { Initial boiling } \\
\text { point: } 156^{\circ} \mathrm{C} \\
10 \% \text { vol. at } 167^{\circ} \mathrm{C} \\
20 \% \text { vol. at } 172^{\circ} \mathrm{C} \\
50 \% \text { vol. at } 188^{\circ} \mathrm{C} \\
90 \% \text { vol. at } 234^{\circ} \mathrm{C} \\
\text { end point of } \\
\text { distillation } 258^{\circ} \mathrm{C}\end{array}$ & - \\
\hline $\begin{array}{l}\text { Boiling Point - saturation } \\
\text { pressure } 760 \mathrm{~mm} \mathrm{Hg}\left({ }^{\circ} \mathrm{C}\right)\end{array}$ & - & -42.2 \\
\hline $\begin{array}{l}\text { Lower flammability limit } \\
\text { (LFL) in } \% \text { by volume of air }\end{array}$ & $0.6-0.7$ & 2.1 \\
\hline $\begin{array}{l}\text { Upper flammability limit } \\
\text { (UFL) in } \% \text { by volume of air }\end{array}$ & $4.9-5.0$ & $9.5-10.1$ \\
\hline $\begin{array}{l}\text { Stoichiometric mixture } \\
\text { composition (air/fuel) }\end{array}$ & 14.3 & 15.7 \\
\hline
\end{tabular}

\section{JET-A1 fuel}

JET-A 1 aviation fuel is dedicated to turboprop engines mainly to drive aircrafts. Jet A-1 is made of components obtained in a specific technological regime in hydrodesulfurization, hydrocracking and distillation processes [15]. Jet Fuel consists of four groups of hydrocarbons:

1. paraffins, isoparaffins, cycloparaffins

2. aromatics

3. naphthalenes

4. olefins

\section{Test stand}

The test was carried out on an AVL experimental common rail, naturally aspirated CI engine. The test equipment was specified in accordance with the Directive of European Parliament and European Council 1999/96 dated 13 December 1999 as well as Regulation (EC) No 715/2007 of the European Parliament and of the Council dated 20 June 2007 and Commission Regulation (EC) No 692/2008 of 18 July 2008.

Propane port injection system used in the experiment was based on standard components of gas injection system such as a two-stage gas regulator with a water jacket and a gas port fuel injector. The gas injector was synchronized with the crankshaft position so that gas injection timing was optimized to reduce loss of gas occurring during valve overlap. It is particularly important from the point of view of the hydrocarbon emission and engine overall efficiency.

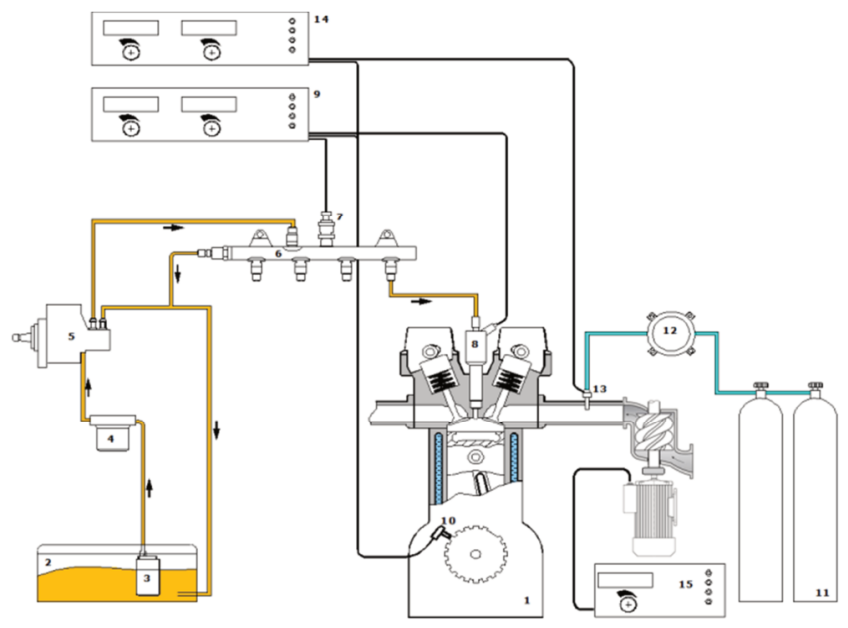

Fig. 1. General layout of dual-fuel system of CI engine supply: 1) engine, 2) Jet A-1 fuel tank, 3) electric fuel pump, 4) fuel filter, 5) high-pressure fuel pump, 6) rail, 7) fuel pressure sensor, 8) Jet A-1 fuel injector, 9) controller of common rail supply system, 10) crank shaft speed sensor, 11) propane container, 12) pressure regulator, 13) propane injector, 14) propane controller supply system,15) engine charging control system

Table 2. Engine characteristics

\begin{tabular}{|l|c|}
\hline Model & AVL 5402 \\
\hline Type & direct injection \\
\hline Number of cylinders & 1 \\
\hline Displacement $\left[\mathrm{cm}^{3}\right]$ & 511 \\
\hline Bore / stroke $[\mathrm{mm}]$ & $85.01 / 90.00$ \\
Cycle & four stroke \\
Compression ratio & 17.5 \\
Maximum power $[\mathrm{kW}]$ & ca.16 \\
Maximum speed $[\mathrm{rpm}]$ & 4200 \\
\hline Valve overlap $[\mathrm{deg}]$ & 80 \\
\hline
\end{tabular}

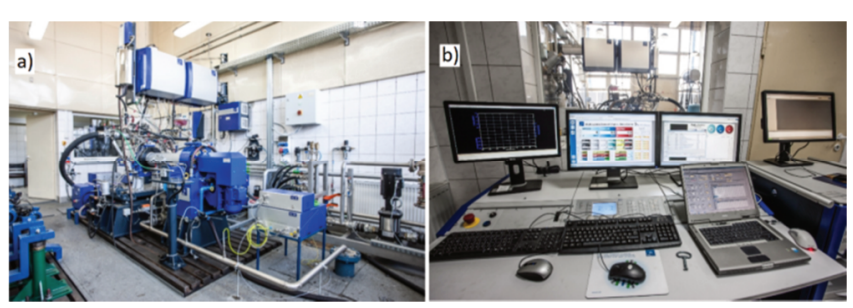

Fig. 2. AVL test bed: (a) general view of the test bed, (b) view of the control room 


\section{Fueling of CI engine with Jet A-1 fuel only}

The first step of the tests was the fuelling of CI engine with Jet A-1 fuel only. There were two options examined:

1. standard injection timing (PCCI)

2. very early injection $(\mathrm{HCCI})$

\subsection{Standard injection timing of Jet A-1 fuel}

In order to realize the Premixed Charge Compression Ignition (PCCI) process two doses of Jet A-1 fuel per cycle were applied. The injection timing and the quantity of the first pilot dose have been selected based on the preliminary studies to obtain the highest thermal efficiency and to reduce the maximum engine pressure to confine the possibility of hammering.

Table 3. Engine adjustment parameters for standard injection timing of Jet A-1 fuel

\begin{tabular}{|l|c|} 
Engine speed [rpm] & 1500 \\
\hline Common rail injection pressure [bar] & $390-760$ \\
\hline $\begin{array}{l}\text { Injection timing of the first dose } \\
\text { [deg BTDC] }\end{array}$ & Variable (10.5-14.9) \\
\hline $\begin{array}{l}\text { Injection timing of the second dose } \\
\text { [deg BTDC] }\end{array}$ & Variable (1.1-6.7) \\
\hline
\end{tabular}

Figure 3 presents the set of cylinder pressure diagrams together with heat release diagrams for different engine load and constant engine speed (1500 rpm). The diagrams are similar to those which are obtained for standard fueling of CI engine with diesel oil only.
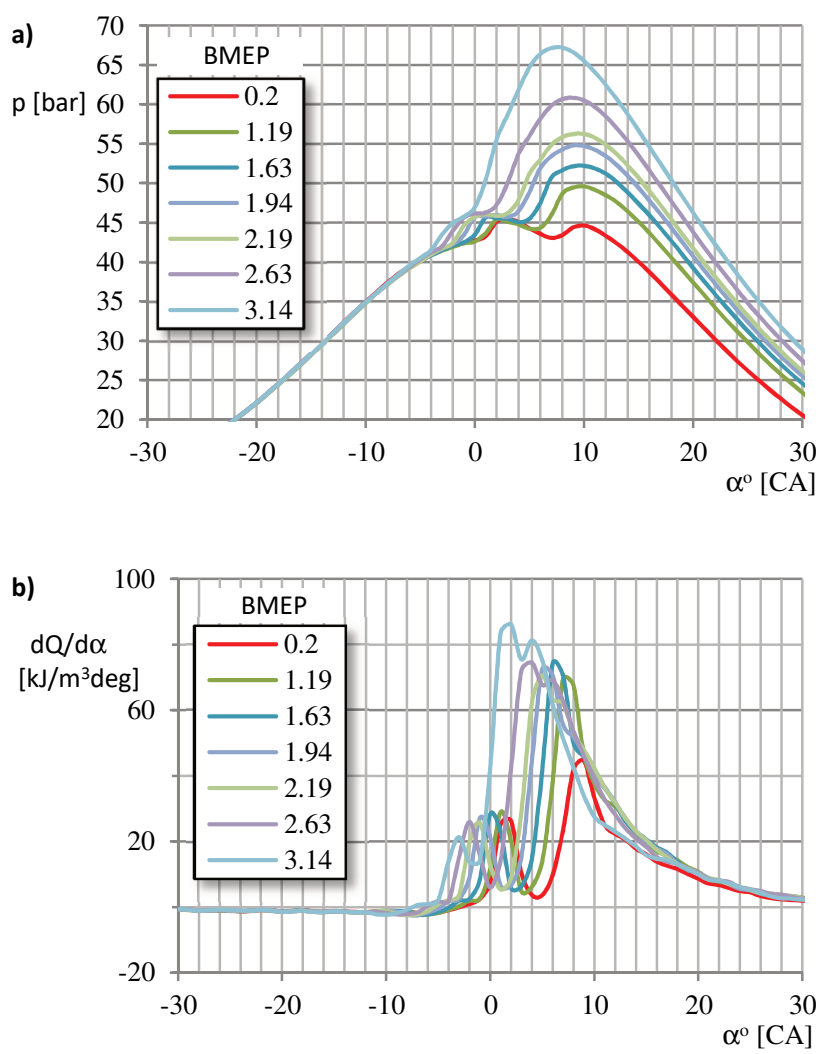

Fig. 3. Pressure diagrams (a) and heat release diagrams (b) for different engine load and constant engine speed $(1500 \mathrm{rpm})$ for fueling with standard injection timing of Jet A-1 fuel

\subsection{Very early injection timing of Jet A-1 fuel}

The application of very early injection timing of the Jet A-1 dose completely changed the combustion process of the fuel. The process starts with small heat release phase and then the heat is released rapidly in the way resembles SI engine heat release diagram. Fig. 4 presents the set of cylinder pressure diagrams together with heat release diagrams for different engine load and constant engine speed $(1500 \mathrm{rpm})$ for the early injection of Jet A-1.

Table 4. Engine adjustment parameters for very early injection timing of Jet A-1 fuel

\begin{tabular}{|l|c|}
\hline Engine speed [rpm] & 1500 \\
\hline Common rail injection pressure [bar] & 350 \\
\hline Injection timing [deg BTDC] & 180 \\
\hline
\end{tabular}
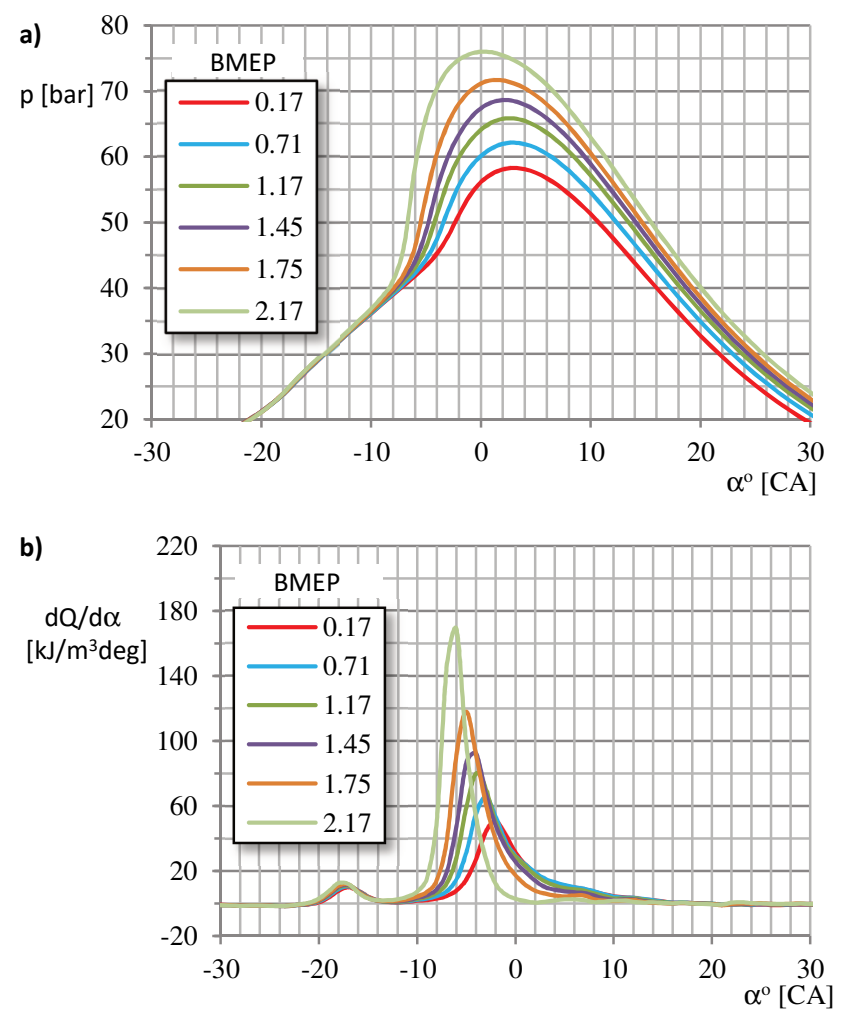

Fig. 4. Pressure diagrams (a) and heat release diagrams (b) for different engine load and constant engine speed $(1500 \mathrm{rpm})$ for fueling with very early injection timing of Jet A-1 fuel

\section{Dual fueling of CI engine with Jet A-1 fuel and propane}

The main objective of the research was to observe the results of combustion process in dual fuel CI engine fueled with Jet A-1 fuel with the addition of propane.

The first step of engine examination was dual fueling with standard injection parameters of Jet A-1. The experiment enable to observe PCCI combustion. The second step was realization of HCCI process with the use of dual fuel mixture. Thanks to application of two fuels (low reactivity fuel - propane and high reactivity fuel - Jet A-1) and modified injection timing of Jet A-1 (very early injection) as well as modification of injection pressure (low), HCCI (homogeneous charge compression ignition) combustion was possible to observe. 
The substitution ratio of propane in the propane/Jet A-1 mixture was defined as:

$$
\mathrm{E}_{\mathrm{P}}=\frac{\mathrm{Q}_{\mathrm{P}} \cdot \mathrm{m}_{\mathrm{P}}}{\mathrm{Q}_{\mathrm{P}} \cdot \mathrm{m}_{\mathrm{P}}+\mathrm{Q}_{\mathrm{JA} 1} \cdot \mathrm{m}_{\mathrm{JA} 1}} \cdot 100
$$

where: $\mathrm{Q}_{\mathrm{P}}$ - propane calorific value, $\mathrm{m}_{\mathrm{P}}$ - dose of propane, $\mathrm{Q}_{\mathrm{JA} 1}$ - Jet A-1 fuel calorific value, $\mathrm{m}_{\mathrm{JA} 1}$ - dose of Jet A-1 fuel.

The total excess air coefficient defined for dual fuelling as:

$$
\lambda=\frac{\dot{\mathrm{m}}_{\mathrm{a}}}{\mathrm{L}_{\mathrm{P}} \cdot \dot{\mathrm{m}}_{\mathrm{P}}+\mathrm{L}_{\mathrm{JA} 1} \cdot \dot{\mathrm{m}}_{\mathrm{JA} 1}}
$$

where: $\mathrm{m}_{\mathrm{a}}$ - air mass flow, $\mathrm{m}_{\mathrm{P}}-$ propane mass flow, $\mathrm{m}_{\mathrm{JA} 1}-$ Jet A-1 mass flow, $L_{P}$ - theoretical air required for complete combustion of $1 \mathrm{~kg}$ of propane, $\mathrm{L}_{\mathrm{JA} 1}$ - theoretical air required for complete combustion of $1 \mathrm{~kg}$ of Jet A-1.

\subsection{Dual fueling of CI engine with Jet A-1 fuel}

\section{and propane - PCCI process}

In order to realize the Premixed Charge Compression Ignition (PCCI) process two doses of Jet A-1 fuel per cycle were applied. Both, the injection timing and the quantity of the first dose of Jet A-1 have been selected based on the preliminary studies to obtain the highest thermal efficiency and to reduce the maximum engine pressure in order to minimize the possibility of hammering.

The injection parameters were the same as for standard fuelling with diesel oil. The change of load was realized by increasing propane dose and its share in the dual fuel mixture. Figure 5 presents the set of cylinder pressure diagrams together with heat release diagrams for different engine load and constant engine speed $(1500 \mathrm{rpm})$ of dual fueled engine with Jet A-1 and propane. In Fig. 5b the increase of ignition delay together with the increase of propane share in the mixture is clearly visible. It means that it is necessary to change the injection parameters to improve engine thermal efficiency [6].

\subsection{Dual fueling of CI engine with Jet A-1 fuel and pro-} pane - HCCI process

Dual fueling of CI engine with Jet A-1 fuel and propane with very early injection of Jet A-1 gave an opportunity to observe HCCI process in the combustion chamber of research engine. In comparison with DF with Jet A-1 and propane in PCCI mode the combustion is very fast and regular. Like for Jet A-1 fueling only preliminary heat release phase was observed. It is very interesting that the maximum cylinder pressure is delayed for higher amount of propane.

Table 5. Engine adjustment parameters for dual fueling with Jet A-1 and propane for PCCI mode

\begin{tabular}{|l|l|}
\hline Engine speed [rpm] & 1500 \\
\hline Common rail injection pressure [bar] & 390 \\
Jet A-1 fuel energy provided per cycle [J] & 250 \\
\hline Injection timing of the first dose [deg BTDC] & 10.5 \\
\hline Injection timing of the second dose [deg BTDC] & 1.1 \\
\hline
\end{tabular}
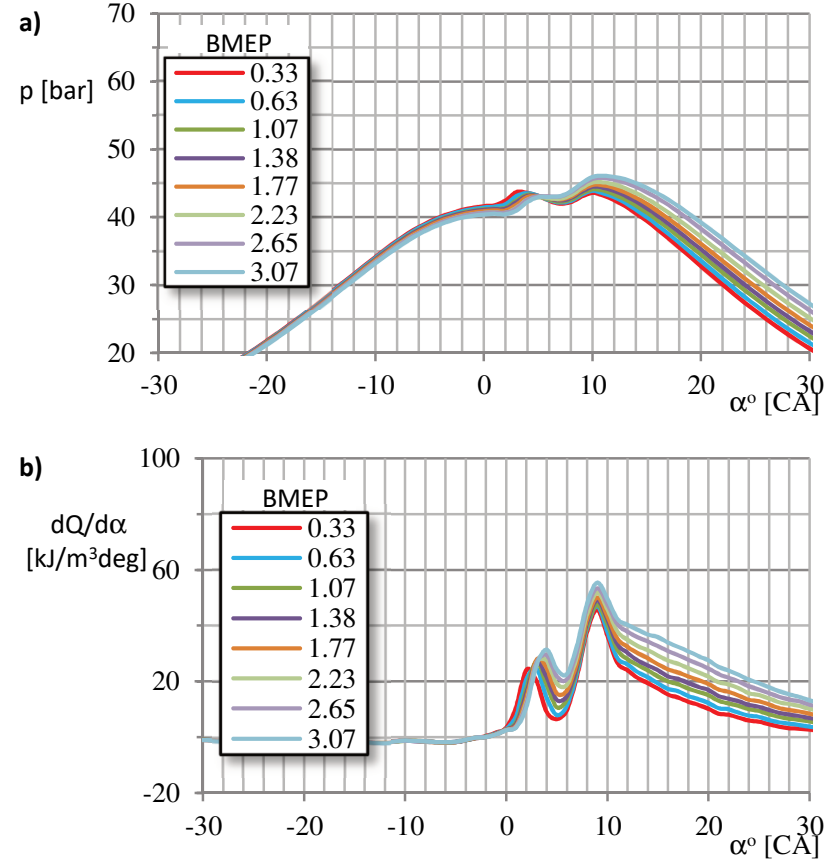

Fig. 5. Pressure diagrams (a) and heat release diagrams (b) for different engine load and constant engine speed $(1500 \mathrm{rpm})$ for dual fueling with Jet A-1 and propane (PCCI mode)

Table 6. Engine adjustment parameters for dual fueling with Jet A-1 and propane for HCCI mode

\begin{tabular}{|l|c|}
\hline Engine speed [rpm] & 1500 \\
Common rail injection pressure [bar] & 360 \\
Jet A-1 fuel energy provided per cycle [J] & 525 \\
\hline Injection timing of Jet A-1 [deg BTDC] & 180 \\
\hline
\end{tabular}
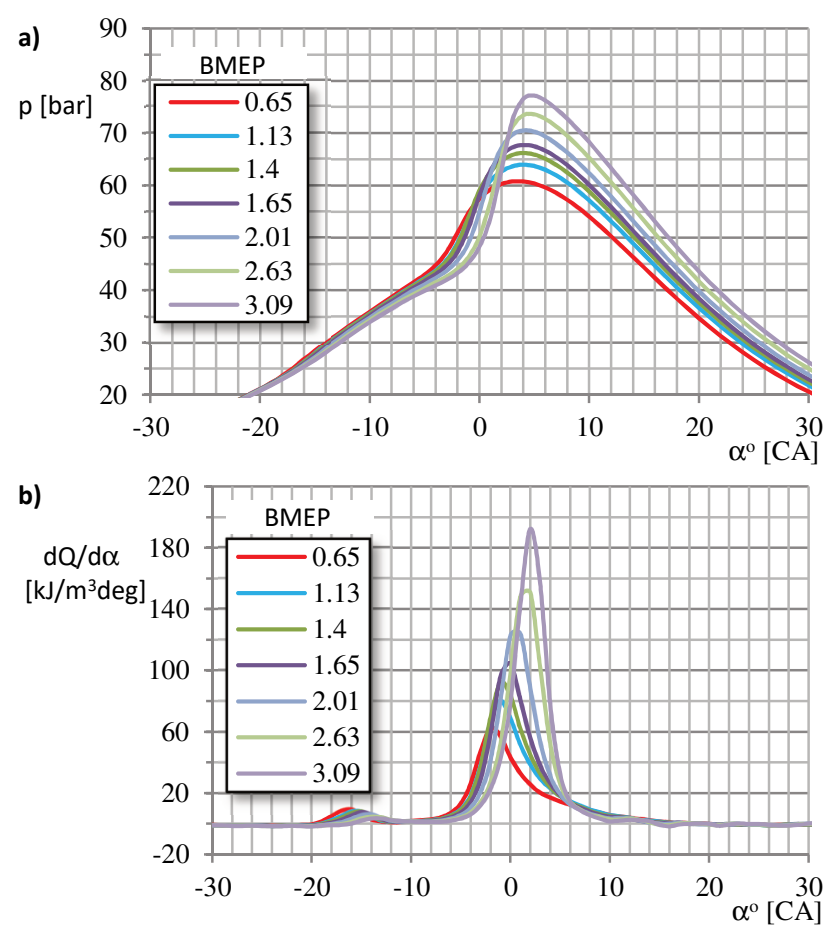

Fig. 6. Pressure diagrams (a) and heat release diagrams (b) for different engine load and constant engine speed $(1500 \mathrm{rpm})$ for dual fueling with very early injected Jet A-1 and propane (HCCI mode) 
To get the set engine speed and BMEP $=0.3$ bar (nearly idle speed $\mathrm{T}=1.5 \mathrm{Nm}$ ) the energy consumed by the engine realized HCCI process was twice as much as the engine running according to PCCI process. It means that the fuel could have been deposited on the cylinder wall. it is necessary to further test the engine to find the right proportion of Jet A-1 and propane.

The results obtained for this part of the test gave very promising dual-fuel strategy that yields good results, especially for low and medium loads, allowing greater control over the timing and duration of the heat release. The results resemble RCCI combustion which is a low-temperature combustion strategy that utilizes early injection of high reactivity fuel to create a reactivity gradient leading to a staged auto-ignition, from the highest reactivity region to the lowest $[2,4,9]$.

\section{Mixture composition and engine emissions}

\subsection{Excess air coefficient}

The conditions for the experiment, especially the way of mixture creation and load control in CI engine resulted in changing of total excess air coefficient $\lambda$ for the range of the engine load Fig. 7. Excess air coefficient $\lambda$ varied from about 5 for minimum load to more than 2 for BMEP $=3$ bar. It is interesting that in the level of excess air coefficient doesn't affect the mechanism of heat release, especially in case of HCCI process observed in case of fuelling the engine with Jet A-1 and dual fuel mixtures of Jet A-1 and propane.

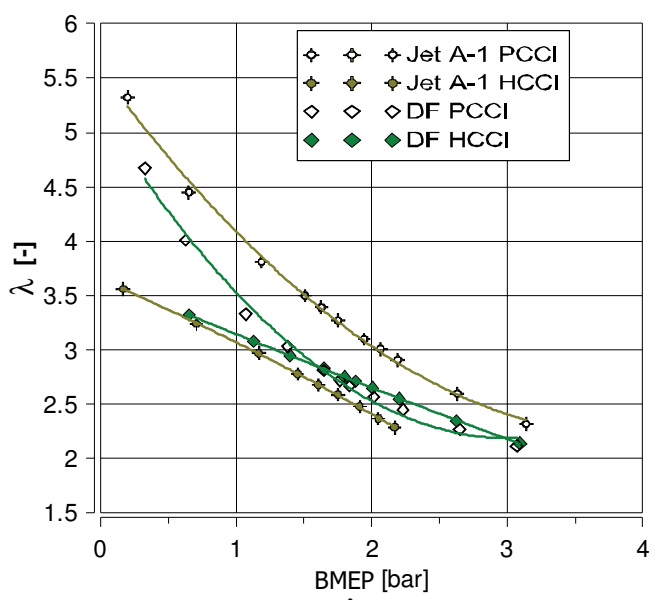

Fig. 7. Total excess air coefficient $\lambda$ vs. BMEP for four modes of fuelling

\subsection{Engine emissions}

The results of the emissions measurement, especially $\mathrm{NO}_{\mathrm{x}}$ emission confirmed that the early injection of Jet A-1 gave the possibility of realization of low-temperature combustion strategy. In both cases - fuelling with Jet A-1 only and dual fuelling the result is similar - it is very low $\mathrm{NO}_{\mathrm{x}}$ emission Fig. 8.

Dual fuel operation usually leads to a higher emission of unburned hydrocarbons mainly due to valve overlap causing a blow of the unburned gas-air mixture out of the cylinder. Usually a relatively high emission of non-methane hydrocarbons (NMHC) appears at low loads because of poor combustion, particularly the phenomenon of flame quenching in a lean mixture caused by its dilution. The measured emission of non-methane hydrocarbons (NMHC) has been presented in Fig. 9. It is very high for HCCI modes of fuelling. It could be discussed if it is a result of flame quenching in a lean mixture $(2<\lambda<5)$ caused by its dilution or/and the non-controlled turbulence inside combustion chamber. It should be analyzed and explain in the further examination connected with visualization of the combustion process.

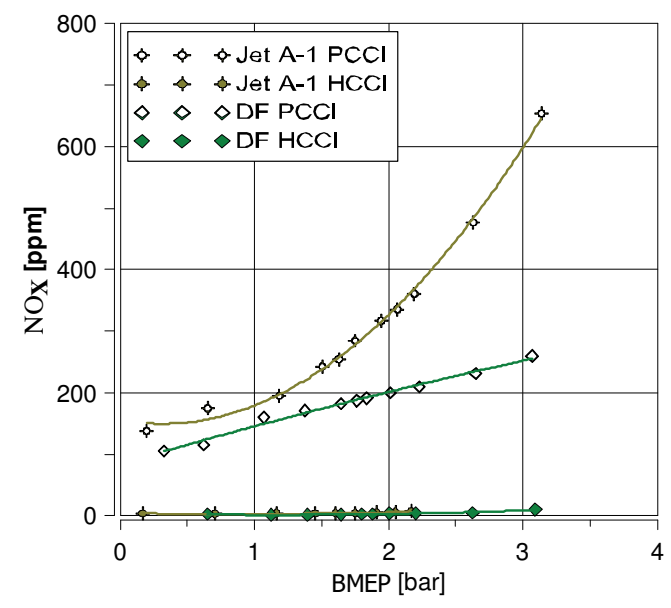

Fig. 8. $\mathrm{NO}_{\mathrm{x}}$ emission vs. BMEP for four modes of fuelling

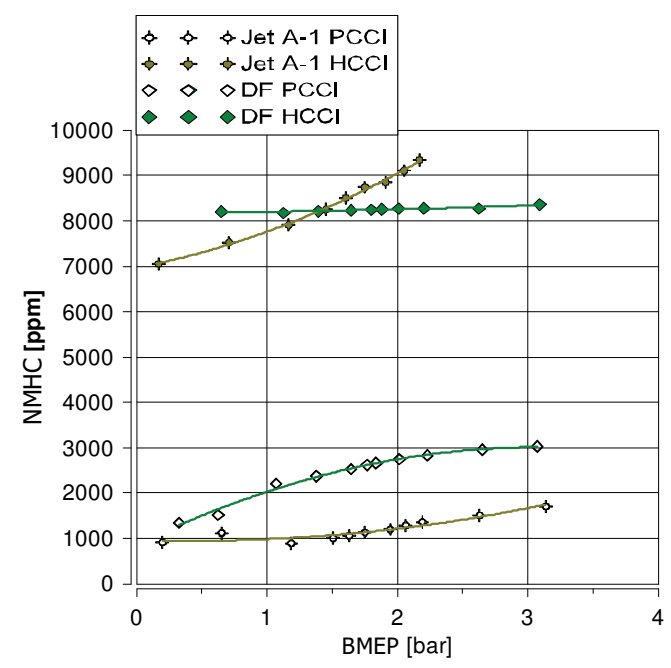

Fig. 9. Emission of non-methane hydrocarbons (NMHC) vs. BMEP for four modes of fuelling

Positive result for HCCI mode of fuelling the engine with Jet A-1 and propane dual fuelling is that the emission of unburned propane is significantly lower for HCCI mode than for standard dual fuelling PCCI - Fig. 10. It was achieve despite of valve overlap. The valve overlap in the experiment was set to $80 \mathrm{deg}$, typical value of this type of engine.

The soot emission for dual fuelling in both cases (HCCI and PCCI) was lower than for fuelling of the engine with Jet A-1 only. Generally this emission is on the low level but for dual fuelling the rise connected with higher load is slower Fig. 11. 


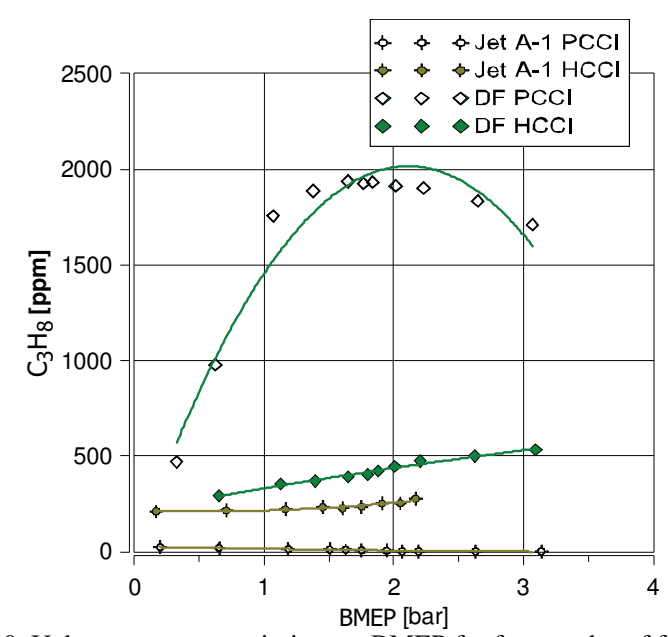

Fig. 10. Unburnt propane emission vs. BMEP for four modes of fuelling

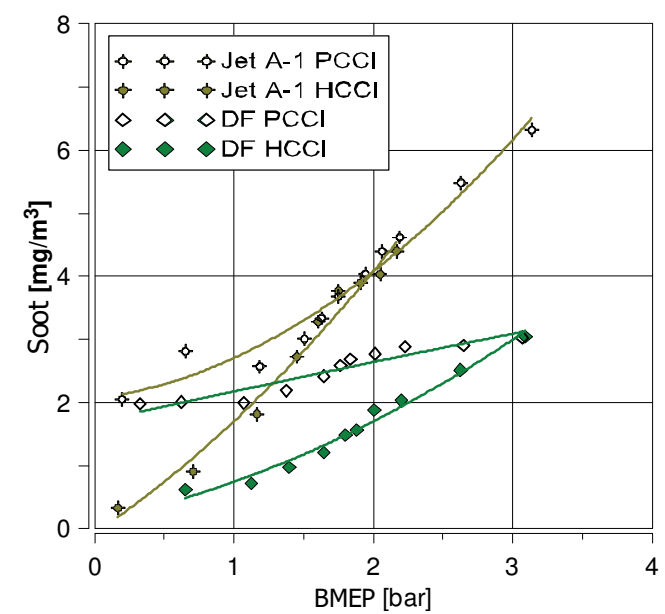

Fig. 11. Soot emission for four modes of fuelling

\section{Engine thermal efficiency}

The engine thermal efficiency diagrams shows very interesting phenomena. When for PCCI options (Jet A-1 only

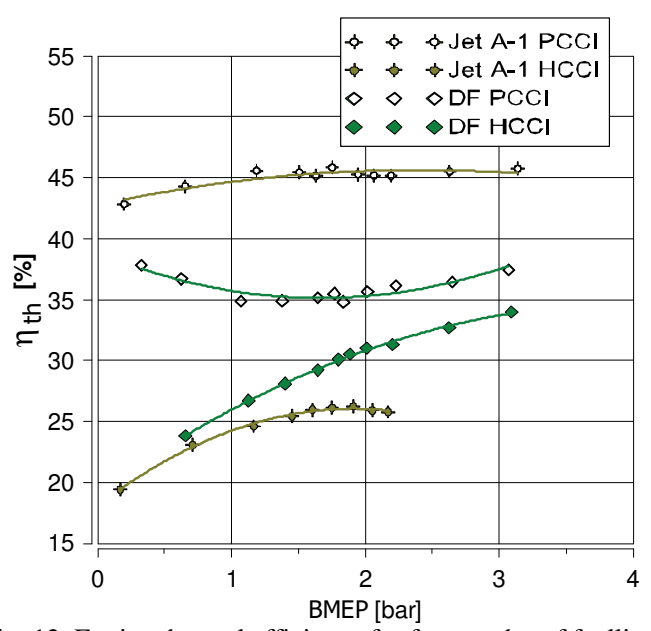

Fig. 12. Engine thermal efficiency for four modes of fuelling and dual fuelling with Jet A-1 and propane) the engine thermal efficiency is relatively high for HCCI modes it starts from very low value but steadily and fast rises with higher engine load. The main problem is the combustion control of HCCI process, especially the maximum cylinder pressure location Fig. 4a, 6a.

The crank angle position for $50 \%$ heat released curves for examined fuelling modes are shown in Fig. 12. Very positive influence of propane is visible in DF HCCI mode. Propane shift the moment of 50\% heat released and thanks to this the engine thermal efficiency rises rapidly.

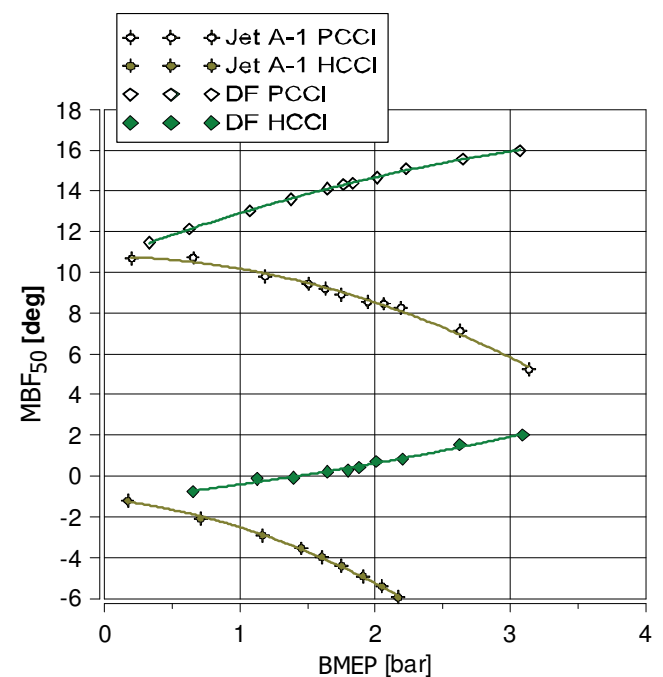

Fig. 13. The crank angle position for $50 \%$ heat released for four modes of fuelling

\section{Conclusions}

The results of the test of utilization of propane as a fuel used together with Jet A-1 for dual fuelling of CI engine are very promising. They show that it is possible to realize HCCI process with the use of alternative fuels combination. The results are very good especially in terms of $\mathrm{NO}_{\mathrm{x}}$ and soot emission. Combustion of homogeneous mixtures in $\mathrm{CI}$ engine demands more control than PCCI process. The results show very interesting potential role of propane to control of combustion of homogeneous dual fuel charge. Propane could be used to shift the position of maximum cylinder pressure for dual fuel HCCI mode. It is very important from the point of view of efficiency and confining of engine hammering phenomena. For dual fuel (Jet A-1 and propane) mixtures burnt in HCCI process unburned propane emission is much lower despite of high value of excess air coefficient $\lambda$ measured during experiments.

The results presented in the paper give the perspective of development of DF CI engine and shows vast area for research work which leads to clean, effective CI engine.

\section{Nomenclature}

DF CI dual fuel compression ignition

(Jet A-1) kerosene-based fuel
PCCI premixed charge compression ignition

HCCI homogeneous charge compression ignition 


\section{Bibliography}

[1] JOHNSON, T.V. Review of diesel emissions and control International Journal of Engine Research. 2009. DOI: 10.1243/ 14680874JER04009

[2] NIEMAN, D.E., DEMPSEY, A.B., REITZ, R.D. Heavyduty RCCI operation using natural gas and diesel. $S A E$ Technical Paper 2012-01-0379, 2012. DOI: 10.4271/201201-0379

[3] PAWLAK, G. The concept of a dual fuel highly efficient internal combustion engine. SAE Technical Paper 01-1480, 2010. DOI: $10.4271 / 2010-01-1480$

[4] PAYKANI, A., KAKAEE, A.H., RAHNAMA, P., REITZ, R.D. Effects of diesel injection strategy on natural gas/diesel reactivity controlled compression ignition combustion. Energy. 2015, 90, 814-826. DOI: 10.1016/j.energy.2015.07.112

[5] REITZ, R.D., GANESH, D. Review of high efficiency and clean reactivity controlled compression ignition (RCCI) combustion in internal combustion engines. Progress in Energy and Combustion Science. 2015, 46, 12-71. DOI: 10.1016/ j.pecs.2014.05.003

[6] SKRZEK, T. Research on the effect of diesel fuel injection parameters on the combustion process in the charged CI engine fuelled with propane. Journal of KONES Powertrain and Transport. 2018, 25(3). DOI: 10.5604/01.3001.0012. 4360
[7] WALKER, N.R., WISSINK, M.L., DEL VESCOVO, D.A., REITZ, R.D. Natural gas for high load dual-fuel reactivity controlled compression ignition in heavy-duty engines. Journal of Energy Resources Technology. 2015, 137(4), 17, 042202-1. DOI: 10.1115/1.4030110

[8] YOUSEFI, A., BIROUK, M. An investigation of multiinjection strategies for a dual-fuel pilot diesel ignition engine at low load. Journal of Energy Resources Technology. 2016, 139(1). DOI: 10.1115/1.4033707

[9] ZHANG, Y., KONG, S.C., REITZ, R.D. Modeling and simulation of a dual fuel (diesel/natural gas) engine with multidimensional CFD. SAE Transactions, Journal of Fuels and Lubricants. 2003, 112(4). DOI: 10.4271/2003-01-0755

[10] www.cleandieseltech.eu/

[11] www.w-erc.com/services/rcci/

[12] www.altogas.com/benefits-of-propane-as-a-clean-fuel

[13] www.smithgas.com/how-propane-is-produced-and-why-itmatters

[14] www.neste.com/companies/products/renewablefuels/renewable-propane

[15] afdc.energy.gov/files/u/publication/2016_propane_market_ outlook.pdf

[16] www.orlen.pl/PL/DlaBiznesu/Paliwa/PaliwaLotnicze/Strony/ PaliwoDoTurbinowychSilnikowJetA1.aspx

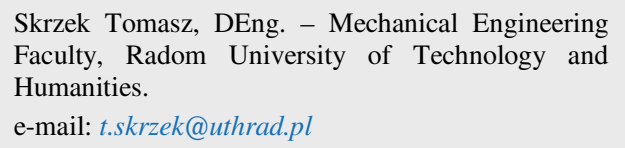

